\title{
10
}

\section{The Prophet, Law, and Constitution in Pakistani Society}

\author{
Jamal Malik
}

The blasphemy laws in Muslim societies have caused a number of problems as they have given much power to the state and also to certain sections of society who have so far been marginalised. Thus, these laws seem to have become a lethal tool for striking back.

Pakistan is among the 15 Islamic countries across the globe where blasphemy laws are enforced. In all these Islamic countries, defiling of the holy Quran, desecration of the Prophet Muhammad and being an atheist are punishable offenses. ${ }^{1}$

In fact, Pakistan has the strictest anti-blasphemy laws in the Muslim world.

This chapter will trace the trajectories of laws related to blasphemy in British India, followed by their translation into the Pakistani constitution and penal law against the backdrop of the discussion on the Islamicity of the fledgling state. In the Islamic Republic of Pakistan, the majority of court judgements on this issue have been pronounced against non-Muslims and minorities. The atrocious consequences of the public handling of these laws will be exemplified with three cases that have caught the media's attention: the assassination of the governor of Punjab in 2011 and the subsequent veneration of his murderer; the lynching of Mashal Khan in early 2017; and the spectacular rise of the religio-political party Labbaik Ya Rasul Allah (Labbaik Yā Rasūl Allāh; Here I am at your service, oh Messenger of God) in late 2017 and 2018. ${ }^{2}$ These cases provide some understanding of the struggles between local factions competing for scarce resources in which the Prophet is the main point of reference.

1 Sajid, "Blasphemy Laws of Pakistan".

2 "Labbaik" is the first word of a particular prayer recited by pilgrims at the outset of and throughout their journey; it is basically a positive humble response to a call, but lately it has also developed into a kind of battle cry, in much the same way as the jihadi usage of "Allahu akbar", as can be seen in the context of the Labbaik Ya Rasul Allah Party in Pakistan. 
Though the blasphemy laws have a long genealogy harking back to colonial rule, their translation into street power was already under way in the 197os, gained political significance since the 1980s, and became a deadly weapon in the twenty-first century.

The sudden hike in the use of the law might indicate an increasingly critical stand vis-à-vis the law itself, as can be seen from the growing number of anti-Islamic statements made by Muslims to be found on the Internet. But the rising number of cases also reflects its growing instrumentalisation by various societal groups for their own purposes:

Majority of blasphemy cases are based on false accusations stemming from property issues or other personal or family vendettas rather than genuine instances of blasphemy and they inevitably lead to mob violence against the entire community. ${ }^{3}$

In making, promulgating, and implementing laws, the respective roles of the state and the military that hold sway in post-colonial countries like Pakistan are as important as the politicians, who have played dubious roles in that context.

\subsection{Blasphemy and the Colonial Legacy}

In tracing the blasphemy laws in countries like Pakistan, one certainly stumbles over the British colonial law and order situation in the nineteenth century: shortly after the abatement of the rebellion of 1857, the Indian Penal Code (IPC) was introduced in 186o. It was the brainchild of Thomas Babington Macaulay (1800-1859) who, as a member of the Law Commission, had drafted the IPC during his time in Bengal in the 1830s. He had also designed the English Education Act 1835 to produce "a class of persons, Indian in blood and colour, but English in taste, in opinions, in morals and in intellect".

The IPC included the promotion of amity between different groups (Section 153-A), proscribing religious offences such as defiling places of worship (Section 295); disturbing religious assemblies (Section 296); trespassing on burial grounds (Section 297); and making utterances that wounding religious feelings (Section 298). These laws were broad in their application across all faiths, originally intended to avoid religious conflicts and to manage the unwieldy religious sentiments between Hindus and Muslims through a "firm adherence to the true principles of toleration". ${ }^{4}$ Nazir opines that

3 Supreme Court of Pakistan, Malik Muhammad Mumtaz Qadri v. the State, 26.

4 Macaulay, A Penal Code, 49-5o. Quoted in Nazir, "A Study", 37. 
Macaulay aimed at fostering "multicultural understanding [and sought to] ring harmony among religious communities and to control religious conflicts". ${ }^{5}$ The suggested freedom of religious discussion and conversion could no longer be established in the early twentieth century, when religious discussions went beyond criticism, "one of the most volatile and tumultuous period [sic] of British Indian history when Hindu[sic]-Muslim riots registered unprecedented rise". ${ }^{6}$

According to A Historical Overview of the blasphemy laws, there were only nine major Hindu-Muslim riots over the course of a century and a half (17131860). That number increased to more than seventy bloody Hindu-Muslim riots during the next half a century (1860-1927). Most of these riots were sparked by the desecration of holy places of both communities, performance of religious festivals, cow protection, and conversion. ${ }^{7}$ But matters came to a head when Arya Samajist Mahashay Rajpal published Rangila Rasul (Rangīlā Rasül; lit., "The Colorful Prophet") in Lahore in 1927.

\subsubsection{Rangila Rasul and Section 295-A of the Indian Penal Code (IPC)}

Rangila Rasul was published as an immediate reaction to pamphlets written by Muslims, such as Sìtā kā Chhinālà ("Sita's adultery") which alleged that Sita, wife of Rama, the hero of Ramayana, was a prostitute, and Unnīswìn saddī kā Mahārishī ("A 19th century Hindu sage"), an attack on Dayanand Saraswati, founder of the Arya Samaj. In 1927, almost seven decades after Macaulay's IPC, the British administration had to introduce more vigorous legislation since Section 153A was not sufficient to prosecute the publisher of Rangila Rasul. In reaction, Muslim groups demanded legislation that outlawed all religious insensitivity to Islam. Hence, Section 295 -A was added, though it made sure that neither academic expressions nor unintentional offense of religious sentiments would be prosecuted:

Whoever, with deliberate and malicious intention of outraging the religious feelings of any class of His Majesty's subjects, by words, either spoken or written, or by visible representations, insults or attempts to insult the religion or the religious beliefs of that class, shall be punished with imprisonment of either description for a term which may extend to two years, or with fine or with both. ${ }^{8}$

5 Nazir, "A Study", 12.

6 Nafees, Blasphemy Laws, 13.

7 Nafees, Blasphemy Laws, 14-15.

8 Nafees, Blasphemy Laws, 13. For a discussion on this booklet and the amendment that followed in the Penal Law, see Nazir, "A Study", 83-9o. 
Even with this amendment, however, it could not be proven that the pamphlet was produced with a deliberate and malicious intention, thus leaving some Muslims indignant. Eventually in 1929, 'Ilm al-Din (now popularly known as Ghāzī 'Ilm al-Dīn Shahīd, the initial honorific meaning "holy warrior" and the latter one meaning "martyr") killed Mahashay Rajpal for publishing Rangila Rasul. He was hanged in 1929.

Yet the issue of blasphemy kept escalating and also affected literary circles when Angare (Angāre; "Burning Coals"), a collection of Urdu short stories published in 1932, stirred another wave of controversy, ${ }^{9}$ as it broke traditional norms in a religious-patriarchal society, offending various Muslims. Angare was banned and until today it has not been republished in Urdu. ${ }^{10}$

The issues around the colonial blasphemy laws did not stop, and in 1935 'Abd al-Qayyum was hanged for killing a man accused of blasphemy in a court in Karachi. Violence connected with the funeral procession of 'Abd al-Qayyum resulted in the deaths of more than a hundred men, women, and children. Further riots took place, wherein atrocities were committed amongst Muslims, Hindus, and Sikhs during partition in 1947. But, as the late Muslim lawyer Asma Jahangir commented:

both cases are crucial examples, showing how Ilam Din and Abdul Qayum both ... took the law in their own hands, becoming popular figures in subsequent history ... Ilam Din became a role model among many Muslims ... especially in contemporary Pakistan, where believers are urged by Muslim clerics to follow Ilam Din Shaheed, the martyr, by killing those who insult the Holy Prophet.11

\subsection{Secular or Muslim Pakistan?}

These blasphemy laws resulting from communal riots were to become a heavy legacy with which Pakistan had to deal. Initially it was left to M. A. Jinnah, the leader of the Muslim League, to maintain law and order and to eradicate bribery, corruption, black-marketing, nepotism, and jobbery. Against the background of the Hindu-Muslim problems, in his first Presidential Address to the Constituent Assembly of Pakistan (11 August 1947), Jinnah called for a secular nation, saying:

$9 \quad$ Nazir, "A Study", 100-113.

10 Coppola, "The Angare Group", 57-69; Mahmud, "Angare".

11 Jahangir and Siddiqui, From Protection to Exploitation, 19. Quoted in Nazir, "A Study", 98. 
if we want to make this great State of Pakistan happy and prosperous, we should wholly and solely concentrate on the well-being of the people.... If you will work in co-operation, forgetting the past, burying the hatchet, you are bound to succeed.... You may belong to any religion or caste or creed - that has nothing to do with the business of the State ... Now I think we should keep that in front of us as our ideal, and you will find that in course of time Hindus would cease to be Hindus, and Muslims would cease to be Muslims, not in the religious sense, because that is the personal faith of each individual, but in the political sense as citizens of the State. ${ }^{12}$

But these clear words were not to be actualised in a post-partition country that was struggling with its identity in the midst of nation-building, political and religious plurality, and reconstruction. Instead, the Objectives Resolution of 1949 was to provide guidelines for making the constitution of the newly born state modelled on a vague ideology and democratic faith of Islam. The constitutional ambiguity and elusiveness with reference to the relation between religion and the state in the wake of contesting normative discussions did leave much room for the accommodation of religion, as the Basic Principles Committee and the Islamic Teachings Board were to advise on matters arising out of the Objectives Resolution which stated that

Muslims shall be enabled to order their lives in the individual and collective spheres in accordance with the teachings and requirements of Islam as set out in the Holy Quran and the Sunnah; Wherein adequate provision shall be made for the minorities [Hindus, Christians, and other non-Muslims] to profess and practice their religions and develop their cultures. ${ }^{13}$

The announcement of "individual and collective spheres" to be ordered "in accordance with the teachings and requirements of Islam as set out in the Holy Quran and the Sunnah" gave plenty of space for religious specialists of sorts to exert their influence on the young state. Members of religio-political parties were of particular importance in pushing their interests through. These included such parties as Jam'iyyat-e 'Ulama'-ye Pakistan led by Barelwis, the Deobandi Jam'iyyat-e 'Ulama'-ye Islam, and notably Jama'at-e Islami, founded

12 Jinnah quoted in Allana, Pakistan Movement Historical Documents, 407ff. (emphasis added).

13 The Objectives Resolution can be found at www.infopakistan.pk/constitution-of-pakis $\tan /$ annex.php. 
by A. A. Mawdudi (d. 1979) ${ }^{14}$ the doyen of political Islam. With the promulgation of the 1956 Constitution, Pakistan became an "Islamic Republic", citing the entire part of the Objectives Resolution under Article 2(A). As Islam became the state religion, Islamic authority had to be protected, though there were sizeable non-Muslim minorities, especially in what was then East Pakistan.

\subsection{The Advent of the Prophet in Pakistani Law and Constitution}

The accommodation of the Objectives Resolution in the 1956 Constitution seemed to have been more of an appeasement of the Muslim League visà-vis the Ahrar Party, founded in 1931, who had been busy hereticising the Ahmadis - a millenarian movement from the Punjab, the majority of whom considered their founder, Ghulam Ahmad of Qadian (d. 1908), to be a prophet. In order to protect the sanctity of the Prophet Muhammad, the Ahrar Party together with others established the Majlis-e Tahaffuz-e Khatm-e Nubuwwat (Association for the Protection of the Finality of the Prophethood) in 1949; ${ }^{15}$ other Islamic scholars issued fatwas calling Ahmadis apostates (murtadds) and published various anti-Ahmadi pamphlets to denigrate them with the aim of inciting Muslims to take the law into their own hands. This resulted in Ahmadi riots during the "Punjab Disturbances of 1953", which "set a precedent that significantly enhanced the power of Sunni groups pressing for a sectarian construction of 'the Pakistani". ${ }^{16}$ East Pakistan also had its own share of communal riots during the 1950s, with brutal killings resulting in nearly 2.1 million Hindus and also Muslims fleeing to West Bengal. ${ }^{17}$

The Ahmadi issue in West Pakistan and the anti-Hindu riots in East Pakistan were easy springboards for different political forces to push through their own agendas. Yet Ahmadis were not declared non-Muslims until 1974. The secession of East Pakistan, which became Bangladesh in 1971, had left the remaining (West) Pakistan more or less homogenously Muslim. This was ideologically underlined by the post-1971 narrative that secession was due to the distance of the preceding governments from Islam. This heightened the influence of

\footnotetext{
14 On these religio-political parties, see Malik, "Jama'at-e Islami"; Malik, "Jam'iyat 'Ulama-e Islam"; Malik, "Jam iyat 'Ulama-e Pakistan"; Malik, "Maududi".

15 On the Ahmadis, see Valentine, Islam and the Ahmadiyya Jama'at; Friedmann, Prophecy Continuous; Zaman, Islam in Pakistan, 166-78 et passim; and Qasmi, The Ahmadis. On the Ahrars, see Awan, Political Islam; Kamran, "The Pre-history of Religious Exclusionism"; and Kamran, "Majlis-i-Ahrar-i-Islam".

16 Shaikh, Making Sense of Pakistan, 6o.

17 Nafees, Blasphemy Laws, 28-33.
} 
religious scholars, as was reflected in the enhancement of a body which eventually grew from only an advisory assembly into a Council of Islamic Ideology that found its way into the 1973 Constitution. The Council's might was also displayed in the notorious hereticisation of the Ahmadis. These developments ran parallel to the global resurgence of religion which radically changed the scenario, with the Pakistan People's Party (PPP) playing a pan-Islamic card: hosting the Second Islamic Summit Conference in Lahore in February 1974 and step by step introducing Islamic regulations.

Z. A. Bhutto (prime minister 1971-77) had come under pressure from various sides, notably religious scholars - Deobandis, Barelwis, and Jama'at-e Islami - who challenged his Islamic socialism. Moreover, the Islamic World League declared Ahmadis non-Muslims in April 1974. A clash between Ahmadi and non-Ahmadi students in July 1974 came at the right time, ${ }^{18}$ resulting in the declaration that Ahmadis are a non-Muslim minority. ${ }^{19}$ Moreover, the Second Amendment to the Constitution of Pakistan, Article 106, added Ahmadis to the category of other non-Muslims while Article 26o(3) introduced the necessity of recognising the finality of the Prophet Muhammad when defining who can be considered Muslim. ${ }^{20}$ Though Bhutto's state-approved takfir had opened Pandora's box, up until 1979 there seem to have been no cases against Ahmadis; and similarly, anti-Ahmadi statements were not prosecuted under Section 295-A of the Pakistan Penal Code (PPC) (deliberate and malicious intention of outraging the religious feelings) and no cases were filed by Muslims against non-Muslims for committing acts of profanity against the Prophet Muhammad or defiling the Qurān. This changed with Zia al-Haqq.

18 For details, see Nazir, "A Study", 184-91.

19 Yet Bhutto seemed not to be in favour of declaring the Ahmadis a minority and pushing them out of state and government institutions, as this was in his view detrimental to the national economy and political stability.

20 Article 106 states: "A person who is not a Muslim and includes a person belonging to the Christian, Hindu, Sikh, Buddhist or Parsi community, a person of the Qadiani Group or the Lahori Group who call themselves Ahmadis or any other name of a Bahai, and a person belonging to any of the Scheduled Castes." Article 26o(3) reads: "A person who does not believe in the absolute and unqualified finality of the Prophethood of Muhammad (peace be upon him), the last of the prophets, and does not believe in, or recognize as a prophet or religious reformers, any person who claims to be a prophet, in any sense of word and any description whatsoever, after Muhammad (peace be upon him) or recognizes such a claimant as a Prophet or religious reformer, is not a Muslim for the purposes of the Constitution or law." 
Against the backdrop of the movement for a "Muhammadan System" (Nizām-e Muștafā), launched by several right-wing political parties under the banner of the Pakistan National Alliance to contest the PPP, Zia seized power from Bhutto in a bloodless coup on 5 July 1977. Shortly after, he announced the Islamisation of the country, which was driven by his Bhutto-paranoia that vanished only with the execution of the ousted prime minister in April 1979. Thereafter the Ahmadi issue became a major rallying force for Zia's religious supporters.

Hence, in 1979, Ahmadis could be prosecuted when performing their religious practices, and in the early 1980s, religious conflicts and controversies began to affect religious freedom, though without legal basis. Some voices even questioned the Islamicity of a punishment meted out to an accused for allegedly defiling the Prophet under Section 295-A of the PPC (deliberate and malicious intention), suggesting that 295-A did not have enough coercive power. It was in this ambiguous legal space that the Urdu book Afāqù Ishtimāliyyāt (English version: "Heavenly Communism") appeared on the scene. Written by the lawyer Mushtaq Raj and published in Lahore in 1983, the book was distributed free among bar members and contained offensive material against all prophets including Muhammad and religion was ridiculed. It was banned under 295-A for outraging the feelings of Muslims and religious specialists demanded jurisdiction to apply blasphemy law with full severity. But there was not yet any law against humiliation of the Prophet. ${ }^{21}$

Since early 1984, religio-political parties had been calling for the introduction of the death sentence in cases of apostasy, demanding a complete ban on the publication and distribution of Ahmadi literature; official curbing of the supposed anti-Islamic and anti-national activities of the Ahmadis; prohibition of Ahmadis referring to their places of worship as mosques or their call to prayer as the adhan; and implementation of the death sentence for those who use derogatory language about the Prophet.

These demands were finally met by the Federal Shariat Court (FSC), established in 1980 to "examine and decide the question whether or not any law or provision of law is repugnant to the injunctions of Islam". In 1984, the court considered punishment of two years and a fine or both as inadequate and repugnant to Islam. It called for the death penalty as the only sufficient

21 Begum, "Defending Prophet's Integrity", 34. Due to pressure of religious scholars Mushtaq Raj was detained under Martial Law. Farhad, "Curbing free thought". 
punishment for defiling the name of the Prophet Muhammad and ruled out pardon - strangely in contradiction to established Hanafi tradition. ${ }^{22}$

With reference to Q 8:13 and 4:65, ${ }^{23}$ the FSC's definition of blasphemy profiled and extended its semantics quite a bit. Blasphemy was now to include reviling or insulting the Prophet in writing or speech; speaking profanity or contemptuously about him or his family; attacking the Prophet's dignity and honour in an abusive manner; vilifying him or making an ugly face when his name is mentioned; showing enmity or hatred towards him, his family, or his companions; accusing, defaming, or slandering the Prophet and his family; refusing the Prophet's jurisprudence or judgement in any matter; rejecting the sunna; disrespect, contempt for, or rejection of the rights of Allah and His Prophet; and rebelling against Allah and His Prophet. ${ }^{24}$

In reaction to the growing street power of the clergy, the government adopted a justificatory narrative. The official thirty-page booklet Qadianis: Threat to Islamic Solidarity - Measures to Prohibit Anti-Islamic Activities asserted that imposing conditions on Ahmadis was due to their anti-Islamic activities and faith being repugnant to Islam; anyone who denied the absolute finality of the Prophet Muhammad "is not a Muslim for the purpose of the constitution or law". The pamphlet stated that

The most sinister conspiracy of the Qadianis after the establishment of Pakistan was to turn this newly Islamic state into a Qadiani kingdom subservient to the Qadiani's pay master. The Qadianis had been planning to carve out a Qadiani State from the territories of Pakistan. ${ }^{25}$

The heretical enemy from within had to be fought. Hence, Ordinance $\mathrm{xx}$ of April 1984 prohibited Ahmadis from publicly practising their religion and identifying themselves as Muslims. Although a death sentence for any gesture even if it is done unintentionally is, juridically speaking, highly controversial, the demand became law in 1986 by virtue of PPC Section 295-C:

22 Qurayshī, Nāmūs-e risālat, 361 ; Mazhar, "The Untold Story".

23 Q 8:13: "That is because they opposed Allah and His Messenger. And whoever opposes Allah and His Messenger - indeed, Allah is severe in penalty." Q 4:65: "But no, by your Lord, they will not [truly] believe until they make you, [O Muhammad], judge concerning that over which they dispute among themselves and then find within themselves no discomfort from what you have judged and submit in [full, willing] submission."

24 Nazir, "A Study", 226ff.

25 Qadianis: Threat to Islamic Solidarity, 24-25. Quoted in Saeed, Politics of Desecularization, 166 . 
Whoever by word, either spoken or written, or by visible representation, or by any imputation, innuendo, or insinuation, directly or indirectly, defiles the sacred name of Holy Prophet Muhammad (peace be upon him) shall be punished with death, or imprisonment for life, and shall also be liable to fine.

Hindu-Muslim hatred had turned into Muslim-Ahmadi hatred; the politics of de-secularisation went hand in hand with religious identity politics. In 1982, Section $295^{-C}$ had stipulated the punishment of life imprisonment or a fine, but in 1986, the punishment was changed to "death or life imprisonment", and on 30 April 1991, the punishment of life imprisonment was turned into "death only”. During Zia al-Haqq's rule (1977-88), a number of additional laws against blasphemy had been introduced that apparently targeted Ahmadis exclusively.

Meanwhile, the issue had become aggravated to the extent that these most frequently invoked blasphemy laws in the PPC are not bailable offenses. A report by Amnesty International made the following observations:

Introduced in 1986, Section $295^{-C}$ is the most severe of the blasphemy laws.... First, the vague wording on what constitutes blasphemy against the Prophet Muhammad means that accusations under this law can be made in a wide range of circumstances. Second, as with Section 298-A, this section operates on the basis of strict liability and therefore does not require proof of specific intent by the accused. Establishing intent is essential with all ordinary criminal offences, but the fact that this is not required in order to prove allegations under blasphemy laws leaves the door open for potential further abuse. ${ }^{26}$

Looking at the increase of blasphemy cases (between 1953 and 2012, approx. 440, including against 258 Muslims [Sunni and Shi'a]; 114 Christians; 57 Ahmadis; and 4 Hindus) and of extra-judicial coercive measures, Amnesty's assessment seems plausible. In fact, those accused of blasphemy often flee the country, and this is particularly the case because

The blasphemy laws have created an environment in which some people, including complainants and their supporters in blasphemy cases, believe themselves entitled to take the law into their own hands, while the police stand aside. The laws have been used as a cover for perpetrators of mob violence. A striking feature has been the disproportionate number of 
victims of such vigilantism being from religious minority groups. [The] motives vary, but can include professional rivalry, personal or religious disputes, hostility towards religious minorities, and seeking economic gains such as money and land. ${ }^{27}$

This mob violence has increased in a spectacular way, as extra-judicial killings and blasphemy accusations go hand in hand and also have institutional requirements: while an accuser must initially register a First Information Report by lodging a complaint at a police station, a key concern regarding police investigations in blasphemy cases is the reliance on fatwas from local clerics on whether the allegations amount to blasphemy. In the current scenario, such fatwas are easily available and enhance the power of religious scholars. The report also observes: "Threats are so high that no one is willing to defend a blasphemy accused, whereas there would be 100 people willing to defend a killer of a blasphemy accused." ${ }^{28}$ Mob violence and fear bring us to the first example of how the blasphemy laws have been turned against the state.

\subsection{The Making of a $G h \bar{a} z \bar{z}$, Peasant Urbanites, and Popular Culture: Mumtaz Qadri}

Mumtaz Qadri (1985-2016) was the elite bodyguard of Punjab Governor Salman Taseer, who had criticised the country's blasphemy law and had filed a mercy petition for Asia Bibi, a Christian who had been sentenced to death by hanging in $2010 .{ }^{29}$ Taseer, an anathema to Nawaz Sharif's governing party, the Muslim League (Nawaz), had called the blasphemy law a "black law". On 4 January 2011, Qadri shot him with twenty-eight bullets (nearly an entire standard magazine) with his officially issued AK-47 assault rifle at a bazaar in Islamabad, having told his colleagues beforehand what he was going to do and that they should not shoot him but arrest him. After the shooting, Qadri threw his weapon down and put his hands up when one of his colleagues aimed at him. Qadri claimed to have been inspired by a sermon delivered by Barelwi cleric Mufti Muhammad Hanif Qurayshi in Rawalpindi, which incited people to take the law into their own hands, saying that people like Taseer who wished to reform Pakistan's blasphemy laws were "wäjib al-qatl", meaning that killing them is obligatory. Following Taseer's murder, Pakistan's only Christian cabinet

27 Amnesty International, “'As Good as Dead", 13.

28 Amnesty International, "As Good as Dead", 34.

29 Bibi and Tollet, Blasphemy. 
member, Federal Minister for Minorities Affairs Shahbaz Bhatti, was also assassinated, on 2 March 2011, after having called for Bibi's release. ${ }^{30} \mathrm{In}$ a recording of a sermon that is no longer available on YouTube, Mufti Quraishi declared:

Let them know those who consider Sunnis as cowards that Allah has honoured us with the courage and power to strangulate those involved in blasphemy, to cut out their tongues, and to riddle their bodies with bullets. For this, nobody can arrest us under any law.

The Barelwi cleric regularly preaches in mosques, including in Bradford, UK. Qadri's act was well received by many Muslims in Pakistan and abroad, and he was eventually to become idolised as a ghäzi. On his last encounter with Taseer, he explained that he had confronted the governor about his words, who in turn denounced the law in even more provocative terms, which Qadri argued was a "grave and sudden provocation" and that he was fully justified in having killed Taseer. ${ }^{31}$ The court, however, established that this story advanced by the appellant about an exchange of words with Taseer at the place of the occurrence was nothing but an afterthought; Qadri's narrative was an important precondition for becoming a martyr. But already before his trial, Qadri had advanced to become a hero:

Mr. Qadri is a hero in Pakistan. There is at least one mosque named after him, so popular it's due to double in size; people come with their children to see him in jail, and seek his blessings; he releases CDs of himself singing those hauntingly beautiful hymns in praise of the prophet. He is considered a religious hero, a mujahid.

$30 \quad$ Guerin, "Pakistan Minorities Minister Shahbaz Bhatti Shot Dead".

31 Qadri's description was as follows: "On the faithful day, I being [a] member of [the] Elite Force I was deployed as one of the member[s] of [the] Escort Guard of Salman Taseer, the Governor Punjab. In Koh-i-Sar Market, the Governor with another [man] after having lunch in a restaurant walked to his vehicle. In [the] adjoining mosque I went for urinating in the washroom and for making ablution. When I came out with my gun, I came across Salman Taseer. Then I had the occasion to address him, 'your honor being the Governor had remarked about blasphemy law as black law, if so it was unbecoming of you.' Upon this he suddenly shouted and said, 'Not only that it is black law, but also it is my shit.' Being a Muslim I lost control and under grave and suddenly [sic] provocation, I pressed the trigger and he lay dead in front of me. I have no repentance and I did it for 'Tahafuz-i-Namoos-i-Rasool'. Salman offered me grave and sudden provocation. I was justified to kill him; kindly see my accompanying written statement U/s 265(F)(5) of Cr. P. C." Quoted in Supreme Court of Pakistan, Malik Muhammad Mumtaz Qadriv. the State, 6. 
says Taseer's son, recognising that Qadri is the murderer, but he also points out that Qadri is a class victim:

he is really a class hero. In societies like ours, societies with colonial histories, religion provides the front; but what is actually going on is class warfare by other means. When Mr. Qadri's defense gestures to my father's "lifestyle ... character and associated matters", what they are really saying, in thinly coded language, is that he was liberal, educated, Westernized; privileged, in a word. The real danger, of course, is to the liberal state, and its values, which also come to be seen as nothing but the affectations of a godless and deracinated class.... It is no accident that it is among the least educated, most backward sections of our society that God finds his most committed soldiers. ${ }^{32}$

After long deliberations, the court considered Qadri's act as "religious vigilantism which may deal a mortal blow to the rule of law in this country where divergent religious interpretations abound and tolerance stands depleted to an alarming level".33 Qadri was sentenced to death - by a judge who most probably did so only under the condition that he be resettled outside the country after the verdict. Qadri was hanged on 29 February 2016, so that his death anniversary could only take place in leap years.

The nation was visibly divided between supporters of the death sentence, the so-called educated among others, and those opposing the verdict, inter alia the underprivileged. The latter, mostly adhering to the Barelwi school of thought, who consider the Prophet Muhammad a paragon, countered the official statement by mobilising an enormous rally at Qadri's funeral. ${ }^{34}$

In constructing the martyrdom narrative, Qadri has been placed in line with several ghāziss, from Ilm al-Dīn whose legacy is carried on in Pakistan, where parks, hospitals, and roads carry his name, to 'Abd al-Qayyum and their epigones, establishing and complementing a genealogy of holy warriors (Figure 10.1).

Qadri has since become a martyr to millions, who make pilgrimage to a shrine (Figure 10.2) erected in his name by his family in the village Bara Kahu, Islamabad, under the supervision of the Mumtaz Qadri Shaheed Foundation. Giant posters of Qadri emblazon buildings not far from a school, while people flock to his shrine, including and especially from abroad.

32 Quoted in Taseer, "A Murderer".

33 Supreme Court of Pakistan, Malik Muhammad Mumtaz Qadriv. the State, 38.

34 See The News, "Historic Gathering"; Boone, "Thousands at Funeral". 


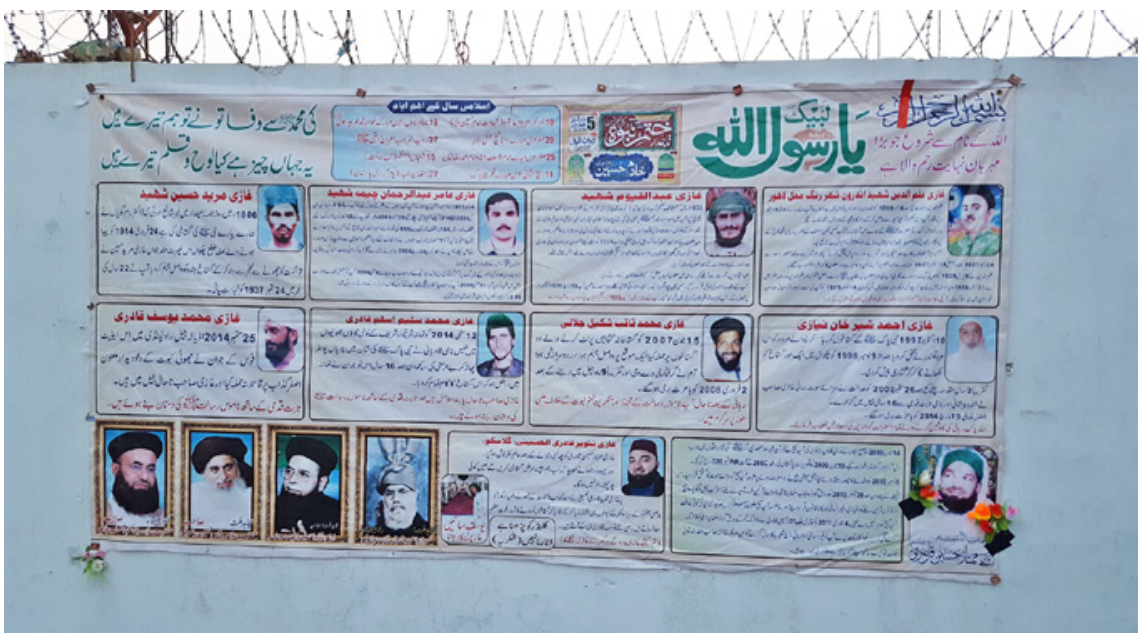

FIGURE 10.1 Poster showing various other ghazis, such as 'Ilm al-Din, at the shrine of M. Qadri

PHOTO: ANONYMOUS, MARCH 2018

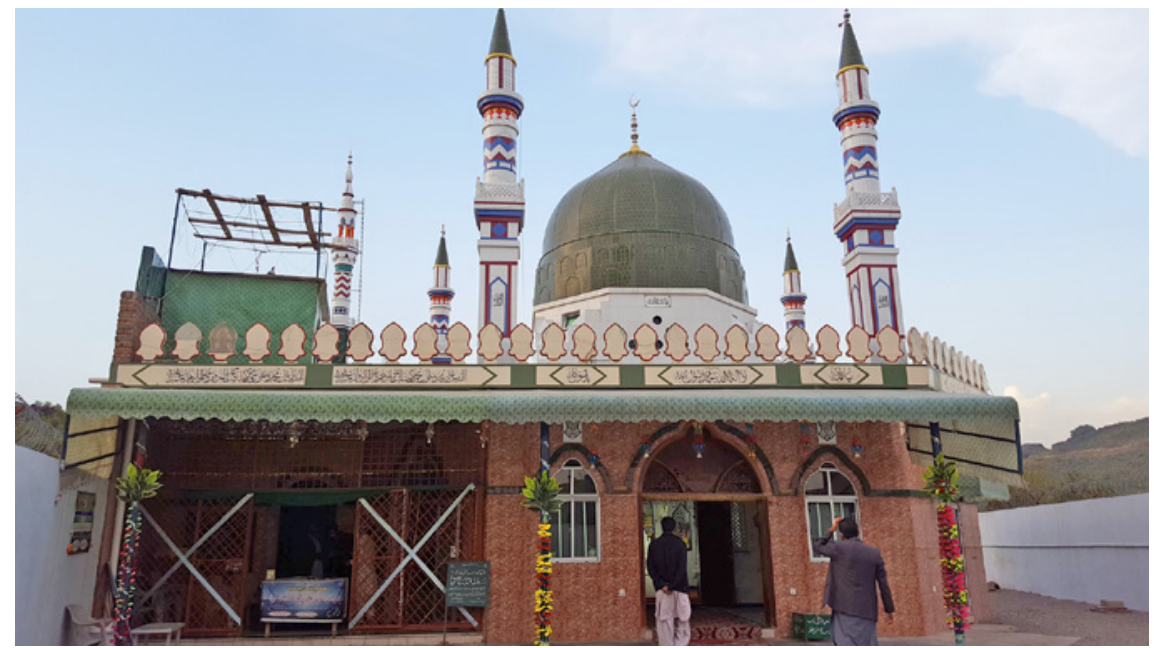

FIGURE 10.2 Qadri's shrine under construction

PHOTO: ANONYMOUS, MARCH 2018

According to Qadri's elder brother and acting custodian (mujäwir) of the shrine, people from abroad, after landing at Islamabad International Airport, first make their vows at the shrine before proceeding home. This international filial bond goes back to the wider Barelwi network, which is refreshed through the visits of clergymen, such as Qureshi, who is actively working for the cause of Khatm-e Nabuwwat, a Barelwi-dominated organisation dedicated 
to upholding not only belief in the finality of the Prophet but also the blasphemy law, and its branches in the UK. Meanwhile, Qadri's 'urs is celebrated every year for three consecutive days, from 28 February to 2 March, thereby overcoming the constraints caused by leap years. The urs is a proven way not only to commemorate the death of Qadri, but also to remember and visualise the Prophet. This anamnesis is very popular among the Barelwis, who practise invocative visualisation of the past and remembrance of the Prophet. He is considered an active agent in the world (hâżir and nāzir) and becomes a reservoir with the potential to turn imitatio Muhammadi into repraesentatio Muhammadi, to bring "a bundle of human excellences associated with the Prophet into the present". ${ }^{35}$ The proselytising wing of the Barelwis, namely, Da'wat-e Islami, ${ }^{36}$ to which Qadri subscribed, are mostly peasant urbanites, ${ }^{37}$ struggling with spatial relocation, subsequent social and cultural adjustment in the city, as well as physical and economic adaptation to urban life. In such a situation, they tend to establish their own urban social networks and enclave cultures, but never losing sight of the normative centrality of Prophetic tradition. The sunnatisation of lifeworlds is institutionalised in a system called Madanī In ‘āmāt ("Medina Rewards"), wherein each day Da'wat-e Islami members tally the divine rewards accrued from fulfilling items on a list of seventytwo pious activities. There is even a Madani In'āmāt app. ${ }^{38}$ In doing so, the common Muslim is raised to the position of and endowed with the responsibility to calling fellow believers to behave in a way worthy of the Prophet. This individual obligation ( fard-e 'ayn) empowers lay Muslims to push through the Qur'ānic commandment to enjoin good and forbid evil (al-amr bi-l-ma' rü f wal-nahy 'an al-munkar). The "commandment to enjoin good and forbid evil" is conflated with resentment based in class differences embodied in heroes such as Qadri. Such resentments can also be traced in the next example, that of Mashal Khan, who was lynched to death on 13 April 2017.

\subsection{Mashal Khan and the Charge of Blasphemy}

Abdul Wali Khan University Mardan (AWKUM) is a newly established educational institution, named after a well-known Pakhtun nationalist leader of Khyber Pakhtunkwa (Pakistan). In 2017, AWKUm became a site of horrifying scenes when a young student was lynched to death amidst shouts of

\footnotetext{
35 See the illuminating remarks in Brown, "Late Antiquity and Islam", 34ff.

36 Gugler, Mission Medina, 100.

37 For this concept, see Simić, The Peasant Urbanites.

38 Gugler, "Daily Piety Drills".
} 
"Allahu akbar" under allegations of blasphemy. Twenty-five-year-old Mashal Khan, the victim of this inimitably brutal incident, was a student at the Mass Communication department of the university. The mob that brutally murdered him accused him of posting "blasphemous content" online.

On 13 April 2017 rumours spread that Mr Khan had posted blasphemous material online, a crime punishable by death in Pakistan. Hundreds of students and some university staff members marched through the campus searching for him. They broke into his room and dragged him out. Widely circulated mobile phone footage showed him being beaten, stamped on and shot. The crowd continued to attack his body after his death. ${ }^{39}$

Mashal belonged to a village in Swabi district, an hour's drive from Mardan University. Born into a poor family, his father, Iqbal Khan, a poet was proud of the numerous trophies and medals Mashal had won and that now adorn his room testify to his brilliance in studies. Mashal's father described him as a "sufi, a philosopher, a poet and a writer by birth". He also remembers his son as "a loving person who talked about peace, patience and non-violence". 40 Being exposed to the outside world, he was well-versed in Western philosophy. He attributed his prudence to his reading habit, "My mind opened after I started reading," and went on to say, "I began to understand the root of our problems in Pakistan." ${ }^{41}$ An admirer of Karl Marx, Mashal considered himself a humanist. He also wanted to be known as a liberal Muslim. His vision of Islam was different from many of his fellow students at the university. Several times this difference of opinion would lead him to become involved in heated debates with more conservative students and every time debate turned to threats. $\mathrm{He}$ knew the repercussions of questioning conventional religious beliefs publicly, such as stating that the children of Adam and Eve must have lived in incestuous relations in order to guarantee human reproduction. He started carrying prayer beads (tasbih $),{ }^{42}$ an act apparently motivated by his struggle to change the perception of his peers who saw him as an "atheist". This, however, did not mean that he would stop articulating his "liberal" unconventional views, which must have upset the clerics who argued that he was legitimising incest.

39 ввс News, "Mashal Khan Case".

40 ввс Newsnight, "Murder on Campus".

41 Bezhan, "Pakistani Student's Views".

42 ввс Newsnight, "Murder on Campus". 
Mashal was a curious, well-read student, but his taste for reading books did not tame his outspoken and activist nature. "He wanted to expose social injustice," and he fought with the university administration for students' rights. ${ }^{43}$ A few days before his death, students at the university staged a strike against the school's administration for the redressal of their grievances. In the wake of the students' protest, he spoke to the Pashto TV channel Khyber. In the course of this interview, he not only highlighted the students' predicaments regarding high fees and unnecessary delay in the degree awarding process, but he also severely criticised the failure of the university administration to pay any heed to the students' demands. He furthermore called all of the senior university officials "thieves" (in Pashto, sing. ghal) ${ }^{44}$ and criticised some for holding multiple offices, questioning the legality of such a practice. Such controversial behaviour had a cost which he paid for with his life. He was labelled a blasphemer, the last resort for silencing unwanted voices, and here the silencing was carried out not through the justice system, but by an angry mob.

What comes with the mob mentality is that people would not even want to verify [the facts of a case]. Mob psychology overrules common sense. Everything is seen as black and white [and] the most unintelligent with the loudest voice commands the mob. 45

During their investigation, police determined there was no evidence that Mashal had committed blasphemy. His killing was ruled to have been premeditated murder. ${ }^{46}$ Hence, the case seemed to have a very profane context, as can be derived from an interview of Mashal's teacher Ziaullah Hamdard, who said that "Mashal's killing was politically motivated," 47 and involved not only students and some teachers, but also members of religio-political parties who aimed at vote-catching in the region, especially Jam'iyyat-e 'Ulama'-ye Islam and Jama'at-e Islami. "In all 57 people were put on trial in connection with the murder, including fellow student Imran Ali, who knew the victim well and pleaded guilty to shooting him."48 The court of law gave Ali the death sentence. Furthermore, the court handed out life terms to five others for murdering a

43 ввс Newsnight, "Murder on Campus"; Geo News English, "Mashal Khan's Teacher Apologises".

44 Seasons TV, "Mashal Khan Last Interview".

45 Ejaz Akram, professor at Lahore University of Management and Sciences, in Amnesty International, "As Good as Dead", 43, as cited in Pirzada, "The Price of Blasphemy".

46 ввс News, "Mashal Khan Case"; в вс Newsnight, "Murder on Campus".

47 For the interview with Hamdard, see Geo News, "Teacher Says".

48 ввс News, "Mashal Khan Case". 
student who was falsely accused of blasphemy, twenty-five others were convicted of lesser offenses, and twenty-six people were acquitted. Interestingly, those who were acquitted were not only cordially welcomed by members of the religio-political parties upon their release from detention on 8 February 2018, but they were also given a "hero's welcome". 49

Mashal's father, Iqbal, was not satisfied with the court's judgement. He said, "I don't understand how several people were acquitted despite very clear videos and other evidence." ${ }^{" 50}$ The matter of the fact is that in Mashal's case, several different threads converged: his being extraordinarily bright caused his fellow students to be jealous; his challenging traditional narratives that were a firm part of the local cultural memory triggered widespread rage; and his reformist zeal infuriated various political party members. These different filaments joined together in an unprecedented and emotionally hyper-charged outburst with the view to silence his voice.

Similar cases are abundant, mostly based on false accusations, be they property issues or personal or family vendettas, eventually leading to mob violence. ${ }^{51}$ The police are impotent, as one officer stated: "How do you stop a violent mob when you have no protection from the state? To take action, the police need the state's backing, but the state is weak."52

Hence, according to the late Asma Jahangir, the blasphemy laws of Pakistan have "controlled and silenced the liberal lobbies" and dissuaded them from religious discourses. ${ }^{53}$ The issue of the blasphemy laws shows that the country is deeply divided between the privileged "Westernized" and the least educated, who find hope in the Prophetic sunna. They are mobilised by religious specialists for assorted interests, a tendency that has gained momentum: from 1927 to 1986, there were only seven blasphemy accusations. But according to statistics collected by the Centre for Social Justice, a Lahore-based advocacy group, at least 1,472 people were charged under Pakistan's blasphemy laws between 1987 and 2016. Of those, 730 were Muslims and 501 were Ahmadis, while 205 were Christians and 26 were Hindus.

The connection of mob violence and blasphemy laws can also be traced in the case of Tehreek-e Labbaik Pakistan (Tahrīk-e Labbaik Pākistān; TLP), an organisation that was born out of a protest movement supporting Qadri.

49 ввс News, "Mashal Khan Case"; RFE/RL, "Released Suspects".

5 в вс News, "Mashal Khan Case".

$5^{1}$ Supreme Court of Pakistan, Malik Muhammad Mumtaz Qadriv. the State, 26.

$5^{2}$ Amnesty International, “'As Good as Dead", 51.

53 Jahangir and Siddiqui, From Protection to Exploitation, 13. 


\subsection{Tehreek-e Labbaik Pakistan (Tahrīk-e Labbaik Pākistān; TLP)}

On 1 August 2015, the wheelchair-bound Barelwi cleric Khadim Hussain Rizvi (b. 1966) founded the Tehreek-e Labbaik Pakistan (TLP) with seventy-two of his followers. ${ }^{54}$ It was registered with the Election Commission of Pakistan in May 2016 under the name Tehreek-e Labbaik Ya Rasool Allah (Tahrìk-e Labbaik Yā Rasūl Allāh, TLYRA ). ${ }^{55}$ The Tehreek-e Labbaik rose to fame after the hanging of Qadri, which it states was unjustifiable. It demands the implementation of shari'a law in Pakistan through a gradual legal and political process, blasphemy being a central issue for the party. The TLP's election posters are often emblazoned with photos of Qadri and others who have killed in the name of the Prophet's honour. ${ }^{56}$

The TLP speaks for those Barelwis who are said to have suffered from a sense of victimisation that has been generated by attacks on shrines and Qadri's execution. "They are drawn towards Tehreek-e-Labbaik Pakistan because of its uncompromising politics of agitation which they see as the only way to attract the attention of the state and have their agenda implemented."57 Their chanting with raised arms Labbaik, labbaik, labbaikyā Rasūl Allāh! ("We stand, we stand, we stand with you, O Messenger of God!") can be intimidating for outsiders, ${ }^{58}$ but fosters solidarity among the followers.

Hence, with the July 2018 election around the corner, the TLP caused a stir when government authorities changed the words "I solemnly swear" (oath) to "I believe" (declaration) in the Elections Bill 2017. The clause related to a candidate's belief in the finality of the prophethood of Muhammad was made not applicable to non-Muslim candidates. In November 2017, as a result of a three-week TLP sit-in at the Faizabad Interchange near Islamabad, the government was forced to restore the previous version of the blasphemy law and the Minister for Law and Justice Zahid Hamid had to resign from his post to avoid having a fatwā issued against him. ${ }^{59}$

54 The number seventy-two is highly loaded with many meanings, such as the number of sects or denominations that are doomed to hell; the number of people martyred along with Husayn b. 'Alī at the Battle of Karbala; and the number of huürīs (beautiful virgins) each Muslim martyr shall receive as companions in paradise.

55 Khan, "Election Symbol"; Dawn, "Tehreek-i-Labbaik Pakistan".

56 Hashim, "Tehreek-e-Labbaik".

57 Kaleem, "The Emergence of Tehreek-e Labbaik Pakistan".

58 Hashim, "Tehreek-e-Labbaik".

59 Hashim, "Pakistan Minister Resigns"; Dawn, "List of Demands"; Dawn, "How the Islamabad Protests Happened"; Butt, "Govt-TLP Accord”. 
Moving on the wave of global populism, ${ }^{60}$ the TLP has become extremely popular in a short time, as can been seen from their extraordinary performance in the by-elections of $2017 .{ }^{61}$ This makes it into more than a mere pressure group, ${ }^{62}$ given the fact that the party secured so many votes at polling booths across Pakistan in the general elections in 2018, that it emerged as the fifth largest party in terms of vote count at the national level and the third largest in the most populous province, the Punjab.

When looking at its constituency, the TLP seems to be more a protest movement than a political party. Voters mostly hail from low-income neighbourhoods in large urban clusters and working-class areas - peasant urbanites - but also trading communities that have suffered from the impacts of globalisation.

the weakening of ... civic forums - such as trade unions, grass-roots level political associations and ethnicity-based organisations - is leaving industrial and commercial workers, especially those who have migrated to a big city from elsewhere, with little option but to seek and find support from religious groups formed around neighbourhood mosques and madrasas. ${ }^{63}$

A jeopardised Prophet comes at the right time and serves to gain political mileage, with religious seminaries and mosques being proven institutions for political campaigning.

At first sight, this exemplifies the clergy's increasing street power. Successfully exploiting the issue of blasphemy, the Barelwis have witnessed a political revival, wherein Khadim Hussain Rizvi ${ }^{64}$ has a major role to play. He is known for his crude language, fiery sermons, and abusive allegations, often in local Punjabi dialect, which are well received by the locals and serve to agitate the audience.

During the campaign at Faizabad Interchange, he lambasted all sorts of politicians, especially the Muslim League government led by Nawaz Sharif, who

6о "In India, the rise of the Bharatiya Janata Party (вJP), the rise of UK Independence Party (UKIP) in the UK, and Donald Trump's victory, all point towards the rise of right-wing nationalistic politics, a factor that should be worrisome for everyone. This could be owing to the increasing trend of post-truth politics, whereby political opinions are formed on emotions, religion and nationalism rather than logic." Mahmood, "13,00o Pakistanis Voted for Far Right Parties".

61 Hashim, "Pakistan Ruling Party".

62 Global Village Space, "Is Khadim Hussain Rizvi Preparing for General Elections?".

63 A political analyst based in Lahore quoted in Kaleem, "The Emergence of Tehreek-e Labbaik Pakistan".

64 Ali, "Who Is Khadim Hussain Rizvi?” 
had voiced critical words vis-à-vis the powerful military establishment and whose name subsequently appeared in the Panama Papers. It is said that during the sit-in, the TLP was supported by the military, whom Khadim Hussain never criticised while there. In fact, the military is said to have supported the movement, as they distributed money among the demonstrators to motivate them to return to their homes. ${ }^{65}$

Analysts have interpreted this increasing street power as the rise of Barelwi politics and fear that this "could be a double-edged sword for society if mishandled by the power brokers. Any induction of extremist doctrines and violent groups among them could lead to an additional layer of sectarian-based discord in society." 66

However, the looming dreadful sectarian-based discord has in fact been postponed thanks to the blasphemy law, which brings a variety of contesting schools of thought onto one platform. Such is the case of Asiya Noreen, alias Asia Bibi. The Punjabi Christian mother of three children was convicted of blasphemy under Section 295-C of the PPC for allegedly defaming the Prophet and was sentenced to death by hanging in 2010. This verdict was confirmed by the Lahore High Court in October 2014. Back in 2009, Bibi and some Muslim women had a quarrel about fetching water when picking fruit in a field. The Muslim women refused to drink water from the same container as Bibi. The exchange got heated, harking back to issues of purity and impurity: as the majority of Christians in Pakistan are descendants of low-caste Hindus who converted during colonial rule, they are considered untouchables and hence often do menial jobs. Lately, they - like the Ahmadis and other minorities have become vulnerable to all sorts of assaults, among others, to blasphemy, and many have left the country. In October 2018, the Supreme Court of Pakistan acquitted Bibi based on insufficient evidence. ${ }^{67}$ Khadim Hussain, for whom large rallies have become a potent tool in his ascent as a politician, reacted to Bibi's acquittal by calling for TLP protests in various cities across Pakistan, ${ }^{68}$ which involved a significant number of like-minded young men. Although Prime Minister Imran Khan issued a strong message to the demonstrators, in an effort to de-radicalise the youth, which was part of the much-talked about and less-implemented National Action Plan (NAP), the government signed a five-point agreement upon which the protesters dispersed peacefully. The

65 Khan, "Why Was Pakistan General Giving Money to Protesters?".

66 Khan, "Why Was Pakistan General Giving Money to Protesters?"; Suleman, "Institutionalisation of Sufi Islam after 9/11".

67 See the Supreme Court of Pakistan, the Criminal Appeal No. 39-L of 2015; Shah, "Pakistan Supreme Court".

68 Geo News, "Asia Bibi's Acquittal”; Griffiths, "Pakistani Christian Asia Bibi”. 
agreement included that the government would allow a review of the petition filed by the respondents in the Bibi case as well as initiate the legal process to place her name on the exit control list (ECL). Moreover, TLP activists arrested during the protests were to be released. In turn, the TLP issued an apology in the event that it hurt anyone's feelings by use of improper words against the state institutions. ${ }^{69}$ Across social media, this agreement was considered a capitulation to a belligerent group. Rumours have since surfaced that Bibi has left the country, and if true, then the TLP and other forces such as the Muttahida Majlis-e Amal (United Council of Action), a political alliance of Islamist and far-right parties in Pakistan, threatened to join forces, feeling that they had been taken in. In fact, in a public statement issued on $3_{1}$ October 2018, the leaders of the TLP not only urged its supporters to take to the streets, but they also said that it was obligatory to kill (wäjib al-qatl) the judges presiding over Bibi's case. Moreover, they asked the generals of Pakistan's army to rebel against the Army Chief. This immediately caused Prime Minister Imran Khan to vow to take stern action against such instigators the very same day in an address to the nation. ${ }^{70}$ In order to end the TLP's nationwide protest, the government and the TLP reached certain terms on 2 November 2018, among others that the government would concede to "initiate the legal process" and place Bibi's name on the ECL. ${ }^{71}$

At the same time, while Bibi's lawyer had left the country due to threats to his life, ${ }^{72}$ the government took severe actions against party members on a nationwide scale, eventually charging the two leaders of the TLP, Khadim Hussain and Pir Afzal Qadri, with treason and terrorism on 1 December 2018.73 It is interesting to note that many of the followers of the TLP as well as the Pākistān Sunnī Tahrīk, a Barelwi organisation founded in 199o, and its allies distanced themselves from the TLP's protest name. Finally, on 29 January 2019, Pakistan's Supreme Court rejected a challenge to the acquittal of Bibi launched by followers of the TLP. ${ }^{74}$ In spite of disclaimers by the government affirming that the Christian woman is still in the country, it is likely that she has left for a secure place outside Pakistan. Be that as it may, the legal actions taken by the government have done little to resolve the predicaments in a highly fragmented society that led to the ordeals described in the above three cases: Salman Taseer, Mashal Khan, and Asia Bibi.

\footnotetext{
69 Alam, "Govt, TLP Sign 5-Point Accord"; Butt, "TLP Ends Countrywide Protest”.

70 Global Village Space, "PM Khan".

71 Bilal, "Government, TLP Reach Agreement".

72 AFP, "Asia Bibi's Lawyer Leaves Pakistan".

73 Dawn, "TLP Leader Khadim Hussain Rizvi Booked under Sedition".

74 в вс, "Asia Bibi Blasphemy Acquittal Upheld by Pakistan Court".
} 


\subsection{Conclusion}

The very fact that sira - etymologically related to being on a journey - slowly became the generic term for the biography of Muhammad's life went along with the Prophet having a paradigmatic role in human life and beyond, being the source of authentic law, the sublimation of the sublime, the perfect individual, a moral and aesthetic ideal, educator, military commander, statesman, and ideal ruler, and so on. All these different roles were to be imitated by Muslims imitatio Muhammadi - through a sunnatisation of lifeworlds. The German Orientalist Rudi Paret (d. 1983) in his Die legendäre Maghāzi-Literatur asserted that: "In case of emergency, the Muslim might deny his faith, but he would never be willing to utter a word of slander against Muhammad or to renounce him, even though he were facing death in case of refusal to do so." And the Canadian W. C. Smith (d. 200o) explained in Modern Islam in India: "Muslims will allow attacks on Allah; there are atheists and atheistic publications, and rationalistic societies; but to disparage Muhammad will provoke from even the most 'liberal' sections of the community a fanaticism of blazing vehemence."75 In the light of this Muslim cultural memory, it is no wonder that blasphemy has become a major issue. In an Islamic Republic, this becomes even more dramatic, since, despite the fact that blasphemy laws provide the legal framework for prosecution, many feel honour-bound to take the law into their own hands to defend the Prophet's integrity, as we have seen with the long line of ghazis and shahids. It is ironic that the laws in Pakistan have a colonial legacy, though in British India "blasphemy" was not used in the "Offences Relating to Religion" as applied in Pakistan. Rather, it was regarded as necessary to protect the religious feelings of diverse religious communities. ${ }^{76}$ But the Objectives Resolution provided ambiguous space between sacred and profane, which gradually - in the wake of the Islamisation drive of the 197os and 198os - came to provide allegations of blasphemy with constitutional and judicial power. In a highly fragmented society with multiple contenders competing for scarce resources, the mobilisation of resentments in the name of the Prophet, such as with the TLP, is easy: as the increasing number of blasphemy cases shows, the law is being abused more blatantly by Muslims - mostly peasant urbanites like Qadri and their leaders - against fellow Muslims and minorities to settle scores or silence opponents, as epitomised by the cases of Bibi and Mashal. But in searching out the actual root of these conflicts, one would do well to

\footnotetext{
75 Paret and Smith are quoted in Schimmel, And Muhammad Is His Messenger, 263n 4 and 5 , respectively.

76 Nazir, "A Study", 207ff.
} 
consider the causal role of societal factors like poverty and injustice. After all, the problems people are facing are not Islamic per se; they are put into a religious discursive garb, to serve certain aims, just like in neighbouring India with its rising Hindu nationalism. There too, economic changes enhanced competition and conflict, mostly in industrial cities where Muslims' share of the population is relatively high (15-6o per cent). By the end of the 195os, for example, tensions resulted from economic misery and increasing social disintegration in urban centres. In the more recent past, the number of Hindu-Muslim communal outbreaks has increased from 240 in 1972 to 525 in $1985,{ }^{77}$ culminating in the riots that immediately followed the destruction of the Babri Masjid as well as later in Gujarat in 2002, leaving around 2,00o dead in the aftermath. Moreover, in September of 2013, on the eve of the Hindu nationalist Bharatiyya Janata Party winning a landslide victory in the 2014 general election, the country witnessed one of its worst riots in Muzaffarnagar. Additionally, 2016 was highly charged with communal tensions throughout the country. More recently, institutions of higher education, whether Muslim or secular, have become targets of nationalist Hindu surveillance. A striking dimension of this communalism is that it has gradually shifted towards rural areas, where in 1985 some 46 per cent and in 1995 more than 5 o per cent of the conflicts took place, while in Pakistan religious outbreaks have been mostly initiated by what has been called peasant urbanites in their struggle to adapt physically, psychologically, and economically in an insecure urban setting. Similarly, in Bangladesh, Islamist extremism has increased since 2001 leaving hundreds dead. There the number of religious specialists affiliated with Islamist organisations has risen to prominence. In Pakistan, this has particularly been the case among the erstwhile peaceful Barelwis, who had been complaining of having been neglected during the hot Cold War in Afghanistan. Now, with the US government's "Muslim World Outreach", financed by USAID since 2003 with the aim of supporting Sufis among others as crucial allies in the struggle against violent Islamists, this might well be the case. But the notion of a romanticised Sufism, docile and aloof from politics, is deceptive, as Sufis were generally peaceful but not necessarily pacifists. This sort of policy has backfired, bringing even erstwhile quietist Barelwis to the forefront, ${ }^{78}$ shaking off their role as the underdogs. This might have caused some power-shift in the religious field; yet the province of Pakhtunkhawa - formerly the North-West Frontier Province - is still the stronghold of Jam'iyyat-e 'Ulama'-ye Islam and partly of the Jama'at-e

77 Gupta, "Changing Role", 193.

78 For more on growing Barewli radicalism, see Suleman, "Institutionalisation of Sufi Islam after 9/11". See also Malik, "The Sociopolitical Entanglements of Sufism”. 
Islami, as the case of Mashal has shown. The device for this power-shift seems to be the blasphemy laws providing a powerful weapon in the contest to decide who speaks for the sunna of the Prophet.

To give a recent example: the Punjab Tahaffuz-e Bunyad-e Islam Act 2020 makes compulsory the printing of the Prophet's epithet "Seal of the Prophets" and the complimentary phrase "peace be upon him" in conjunction with the appearance of his name. Similarly, objectionable comments about the Prophet, ahl-e bait (members of Muhammad's family), the first four Sunni caliphs, ashāb (contemporaries of Muhammad) and ummahāt al-muminin (Muhammad's wives) will also be deemed as cognizable offenses by the Directorate General of Public Relations (DGPR). Moreover, some course books for schools are to be censured and banned, although they merely quote from history books and have already been taught for many years.

The biggest concern with this bill, however, seems to be that DGPR will ban publishing or importing any book or text that does not have such titles and complimentary phrases for prophets, companions, etc. Yet most books outside Pakistan do not use these titles and thus cannot be imported anymore. More significant still is the fact that none of the classical Islamic books use these titles or phrases, not even hadith books or the Quran itself. It is clear that Sunni - Shia issues will further be heated, and Barelwi - Deobandi problems will get worse. The impracticability of the law is obvious, and it seems that no Islamic scholar has been consulted in that regard, since the law would have tremendous repercussions for the freedom of thought in Pakistan and fuel simmering inter- and intra-religious disputes. Nevertheless, some influential religious scholars have realised how important it is to promote and protect religious freedom, which can help undermine terrorism and enhance national security. Scores of special training programmes are being offered by various institutions to promote the appreciation of other voices, be it on the national $7^{79}$ or international level. ${ }^{80}$ However, as long as the real issues like poverty, injustice, and political suppression are not properly solved, all such training programmes will be in vain. Addressing these issues may well be the best solution, if pursued in the appropriate way, to follow the sunna understood as an indication of a general direction, open to responsible, contextual, and consensual interpretation.

79 Daily Pakistan Observer, "Ilm-o-Aman Foundation Training Programme".

8o Lapaeva, "The List of Leaders of Religious Confessions/Organizations". 


\section{Bibliography}

AF P. "Asia Bibi's Lawyer Leaves Pakistan Citing Threats to His Life", Dawn, 3 November 3 2018. Accessed 28 December 2018. www.dawn.com/news/1443317.

Alam, I. "Govt, TLP Sign 5-Point Accord", The Nation, 2 November 2018. Accessed 28 December 2018. https://nation.com.pk/o3-Nov-2018/govt-tlp-sign-5-point -accord.

Ali, K. "Who Is Khadim Hussain Rizvi?", Dawn, 5 December 2017. Accessed 29 December 2018. www.dawn.com/news/1374182.

Allana, G. Pakistan Movement Historical Documents, Karachi, Department of International Relations, University of Karachi, [1969].

Amnesty International. “'As Good as Dead': The Impact of the Blasphemy Laws in Pakistan", London, Amnesty International, 2016.

Awan, S. Political Islam in Colonial Punjab: Majlis-i-Ahrar, Oxford, Oxford University Press, 2010.

ввс News. "Mashal Khan Case: Death Sentence for Pakistan 'Blasphemy' Murder", 7 February 2018. Accessed 28 December 2018. www.bbc.com/news/world-asia -42970587 .

вв С News. "Asia Bibi Blasphemy Acquittal Upheld by Pakistan Court", 29 January 2019. Accessed 1 February 2019. www.bbc.com/news/world-asia-47040847.

ввс Newsnight. "Murder on Campus: The Story of Mashal Khan - BBC Newsnight", YouTube, 3 July 2017. Accessed 28 December 2018. www.youtube.com/watch? $\mathrm{v}=$ ZexWiSO_QUI.

Begum, U. "Defending Prophet's Integrity”, al-Basira 2/4 (2013), 21-41.

Bezhan, F. "Pakistani Student's Views, Social Media Presence Stand Out after Lynching”, Radio Free Europe, 20 April 2017. Accessed 4 July 2018. www.rferl.org/a/pakistan -student-khan-mob-killing-social-media-/28441191.html.

Bibi, A., and A. I. Tollet. Blasphemy: A Memoir: Sentenced to Death over a Cup of Water, Chicago, Chicago Review Press, 2013.

Bilal, R. "Government, TLP Reach Agreement: State to Take Legal Measures to Place Asia Bibi's Name on ECL”, Dawn, 2 November 2018. Accessed 11 March 2021. www .dawn.com/news/1443123.

Boone, J. "Thousands at Funeral of Pakistani Executed for Murdering Governor", The Guardian, 1 March 2016. Accessed 28 December 2018. www.theguardian.com/ world/2016/mar/o1/funeral-pakistani-mumtaz-qadri-executed-salmaan-taseer.

Brown, D. "Late Antiquity and Islam: Parallels and Contrasts," in B. D. Metcalf, ed., Moral Conduct and Authority: The Place of Adab in South Asia Islam, Berkeley, University of California Press, 1984, 23-37.

Butt, H. "TLP Ends Countrywide Protest after Agreement with Government", The Business, 2 November 2018. Accessed 28 December 2018. https://www.geo.tv/ 
shows/special-reports/217098-tlp-ends-countrywide-protest-after-agreement-withgovernment. Accessed 27 August 2021.

Butt, T. "Govt-TLP Accord: Painful Realities", The News, 28 November 2017. Accessed 28 December 2018. www.thenews.com.pk./print/249945-govt-tlp-accord -painful-realities.

Coppola, C. “The Angare Group: The Enfants Terribles of Urdu Literature”, Annual of Urdu Studies 1 (1981), 57-69.

Daily Pakistan Observer. "Ilm-o-Aman Foundation Training Programme", 18 May 2016. Accessed 29 December 2018.

Dawn. "How the Islamabad Protests Happened", 27 November 2017. Accessed 28 December 2018. www.dawn.com/news/137280o.

Dawn. "List of Demands Put Forward by TLY and Accepted by Govt for Ending the Faizabad Protest”, 29 November 2017. Accessed 28 December 2018. www.dawn.com/ news/1373197.

Dawn. "Tehreek-i-Labbaik Pakistan", 19 July 2018. Accessed 28 December 2018. www .dawn.com/news/1414545.

Dawn. "TLP Leader Khadim Hussain Rizvi Booked under Sedition, Terrorism Charges: Information Minister", 1 December 2018. Accessed 28 December 2018. www.dawn .com/news/1448807.

Farhad, "Curbing free thought", Index on Censorship 14:2 (1985), 33-36.

Friedmann, Y. Prophecy Continuous: Aspects of Ahmadi Religious Thought and Its Medieval Background, Berkeley, University of California Press, 1988.

Geo News. "Teacher Says Mashal Was Not Given Chance to Prove His Innocence", 18 April 2017. Accessed 28 December 2018. www.geo.tv/latest/13846o.

Geo News. "Asia Bibi's Acquittal: TLP Protests in Various Cities across Pakistan", 31 October 2018. Accessed 28 December 2018. www.geo.tv/latest/216749-asia -bibi-acquittal-tehreek-e-labbaik-pakistan-tlp-protests-in-various-cities-across -pakistan.

Geo News English. "Mashal Khan's Teacher Apologises to Nation for Failing to Save Him", YouTube, 17 April 2017. Accessed 28 December 2018. www.youtube.com/ watch?v=EJ2ejBdDWQA.

Global Village Space. "Is Khadim Hussain Rizvi Preparing for General Elections?", 4 April 2018. Accessed 28 December 2018. www.globalvillagespace.com/is-kha dim-hussain-rizvi-preparing-for-general-elections/.

Global Village Space. "PM Khan Vows to Take Stern Action against 'Blackmailers' in Latest Address to Nation", 31 October 2018. Accessed 28 December 2018. www .globalvillagespace.com/pm-khan-vows-to-take-stern-action-against-blackmailers -in-latest-address-to-nation/. 
Griffiths, J. "Pakistani Christian Asia Bibi Has Death Penalty Conviction Overturned", CNN, 31 October 2018. Accessed 28 December 2018. https://edition.cnn.com/ 2018/10/31/asia/pakistan-asia-bibi-blasphemy-intl/index.html.

Guerin, O. "Pakistan Minorities Minister Shahbaz Bhatti Shot Dead", ввс News, 2 March 2011. Accessed 28 December 2018. www.bbc.com/news/world-south-asia -12617562 .

Gugler, T. K. Mission Medina: Da'wat-e Islami und Tabligi Gama'at, Würzburg, Ergon, 2011.

Gugler, T. K. "Daily Piety Drills for Lay Preachers in South Asia: The Tablighi Jama'at and Da'wat-e Islami", in I. Weismann and J. Malik, eds, Culture of Da'wa: Islamic Preaching in the Modern World, Salt Lake City; The Utah University Press, 2020, 96-110.

Gupta, R. "Changing Role and Status of the Muslim Minority in India: A Point of View", Journal of Muslim Minority Affairs 5/1 (1984), 181-202.

Hashim, A. "Pakistan Ruling Party Wins Key By-election in Lahore", Al Jazeera, 17 September 2017. Accessed 28 December 2018. www.aljazeera.com/news/2017/o9/ voting-concludes-key-pakistan-election-170917124556192.html.

Hashim, A. "Pakistan Minister Resigns, Ending Islamabad Standoff", Al Jazeera, 27 November 2017. Accessed 28 December 2018. www.aljazeera.com/news/2017/11/ pakistan-minister-resigns-protester-stand-17112707142106o.html.

Hashim, A. "Tehreek-e-Labbaik: New far Right Campaigns against 'Blasphemy", Al Jazeera, 6 July 2018. Accessed 28 December 2018. www.aljazeera.com/indepth/ features/tehreek-labbaik-campaigns-blasphemy-180705154014562.html.

Jahangir, A., and M. Siddiqui. From Protection to Exploitation: The Laws against Blasphemy in Pakistan, Lahore, AG Hs Legal Aid Cell, 2007.

Kaleem, M. "The Emergence of Tehreek-e Labbaik Pakistan on Karachi's Political Map", Herald, 20 September 2018. Accessed 28 December 2018. https://herald.dawn.com/ news/1398669.

Kamran, T. "Majlis-i-Ahrar-i-Islam: Religion, Socialism and Agitation in Action", South Asian History and Culture 4 (2013), 465-82.

Kamran, T. "The Pre-history of Religious Exclusionism in Contemporary Pakistan: Khatam-e-Nubuwwat 1889-1953", Modern Asian Studies 49 (2015), 1840-74.

Khan, I. A. "Election Symbol Allotted to Tehreek-i-Labbaik Pakistan", Dawn, 1 October 2017. Accessed 28 December 2018. www.dawn.com/news/1361164.

Khan, M. I. "Why Was Pakistan General Giving Money to Protesters?", ввс News, 29 November 2017. Accessed 28 December 2018. www.bbc.com/news/world-asia -42149535 .

Lapaeva, O. "The List of Leaders of Religious Confessions/Organizations, and Also the Political Figures Participating in the IV Congress of Leaders of World and 
Traditional Religions", Congress of World Religions. Accessed 29 December 2018. http://religions-congress.org/index.php?lang=english (accessed 26.o8.2021).

Macaulay, T. B. A Penal Code Prepared by Indian Law Commissioners, Calcutta, Bengal Military Orphan Press, 1837.

Mahmood, H. "13,0oo Pakistanis Voted for Far Right Parties: Should the Remaining Be Worried?", Tribune, 27 September 2017. Accessed 31 August 2021. https://tribune .com.pk/article/57552/1300o-pakistanis-voted-for-far-right-parties-should-theremaining-be-worried.

Mahmud, S. "Angare and the Founding of the Progressive Writers' Association", Modern Asian Studies 30/2 (1996), 447-67.

Malik, J. "Jama'at-e Islami", in R. C. Martin, ed., Encyclopedia of Islam and the Muslim World, Vol. 1, 2nd ed., Farmington Hills, Macmillan Reference USA, 2016, 575-77.

Malik, J. "Jam'iyat 'Ulama-e Islam", in R. C. Martin, ed., Encyclopedia of Islam and the Muslim World, Vol. 2, 2nd ed., Farmington Hills, Macmillan Reference USA, 2016, 578-80.

Malik, J. "Jam'iyat 'Ulama-e Pakistan", in R. C. Martin, ed., Encyclopedia of Islam and the Muslim World, Vol. 1, 2nd ed., Farmington Hills, Macmillan Reference USA, 2016, 580-81.

Malik, J. "Maududi", in R. C. Martin, ed., Encyclopedia of Islam and the Muslim World, Vol. 2, 2nd ed., Farmington Hills, Macmillan Reference USA, 2016, 708-10.

Malik, J. "The Sociopolitical Entanglements of Sufism", in A. Salvatore, R. Tottoli, and B. Rahimi, eds, The Wiley Blackwell History of Islam, Oxford, John Wiley \& Sons Ltd., 2018, 587-6o6.

Mazhar, A. "The Untold Story of Pakistan's Blasphemy Law", Dawn, 31 October 2018. Accessed 29 December 2018. www.dawn.com/news/1149558.

Nafees, M. Blasphemy Laws in Pakistan: A Historical Overview, Islamabad, Center for Research and Security Studies (CRSs), 2010.

Nazir, F. A. "A Study of the Evolution of Legislation on Offences Relating to Religion in British India and Their Implications in Contemporary Pakistan", PhD diss., University of Edinburgh, 2013.

The News. "Historic Gathering at Qadri's Funeral in Rawalpindi", 2 March 2016. Accessed 28 December 2018. www.thenews.com.pk/print/102301-Historic-gathering -at-Qadris-funeral-in-Rawalpindi.

Pirzada, S. A. "The Price of Blasphemy in Pakistan", Al Jazeera, 28 August 2012. Accessed 28 December 2018. www.aljazeera.com/indepth/features/2012/o8/2012 82714106498222.html.

Qadianis: Threat to Islamic Solidarity - Measures to Prohibit Anti-Islamic Activities, Islamabad, Pakistan Publications, 1985.

Qasmi, A. U. The Ahmadis and the Politics of Religious Exclusion in Pakistan, London, Anthem Press, 2014. 
Quraishī, M. I. Nāmūs-e risālat awr qānūn-e tawhīn-e risālat, 2nd ed., Lahore, Nāshirān o Tājirān e Kutub, 1999.

RFE/RL. "Released Suspects in Pakistani 'Blasphemy' Lynching Case Given Hero's Welcome”, Gandhara, 8 February 2018. Accessed 28 December 2018. https:// gandhara.rferl.org/a/pakistan-mashal-khan-muder-verdic/29028149.html.

Saeed, S. Politics of Desecularization: Law and the Minority Question in Pakistan, Cambridge, Cambridge University Press, 2016.

Sajid, S. M. "Blasphemy Laws of Pakistan: Symbols of Islamic Fanaticism", Crisis Magazine, 9 March 2016. Accessed 29 December 2018. www.crisismagazine.com/ 2016/blasphemy-laws-of-pakistan-symbols-of-islamic-fanaticism.

Schimmel, A. And Muhammad Is His Messenger: The Veneration of the Prophet in Islamic Piety, Chapel Hill, University of North Carolina Press, 1985.

Seasons Tv. "Mashal Khan Last Interview with Khyber News", YouTube, April 13, 2017. Accessed 28 December 2018. www.youtube.com/watch?v=DOUkmt3j9Lw.

Shah, Z. H. "Pakistan Supreme Court, Blasphemy Laws and Fate of Asia Bibi and a Whole Nation", The Muslim Times, 8 October 2018. Accessed 28 December 2018. https://themuslimtimes.info/2018/10/o8/pakistan-supreme-court-blasphemy -laws-and-fate-of-asia-bibi-and-a-whole-nation/.

Shaikh, F. Making Sense of Pakistan, Oxford, Oxford University Press, 2012.

Simić, A. The Peasant Urbanites: A Study of Rural-Urban Mobility in Serbia, New York, Seminar Press, 1973.

Suleman, M. "Institutionalisation of Sufi Islam after $9 / 11$ and the Rise of Barelvi Extremism in Pakistan", Counter Terrorist Trends and Analyses 10/2 (2018), 6-10.

Supreme Court of Pakistan. The Supreme Court of Pakistan Judgment, Malik Muhammad Mumtaz Qadri v. the State, Criminal Appeals, No. 210 and 211, 2015. https://www.refworld.org/pdfid/563891794.pdf (accessed 31 August 2021).

Supreme Court of Pakistan. The Criminal Appeal No. 39-L of 2015, Judgment of the Supreme Court of Pakistan, Islamabad, 31 October 2018. https://www.supremecourt .gov.pk/downloads_judgements/Crl.A._39_L_2015.pdf. (Accessed 31 August 2021).

Taseer, A. "A Murderer - and Also a Victim of Place", The New York Times, 20 November 2015. Accessed 28 December 2018. www.nytimes.com/2015/11/21/opinion/a -murderer-and-also-a-victim-of-place.html.

Valentine, S. R. Islam and the Ahmadiyya Jama'at: History, Belief, Practice, New York, Columbia University Press, 2008.

Zaman, M. Q. Islam in Pakistan: A History, Princeton, Princeton University Press, 2018. 